\title{
Konstrukcija i validacija Skale vjerom inspiriranoga društvenog angažmana (VIDA) među mladima u Hrvatskoj
}

\author{
DOI: $10.5613 /$ rzs.50.3.4 \\ UDK 316.74:2](497.5) \\ 316.648-053.8"465*18/25"(497.5):2 \\ 303.2:2-184 \\ Izvorni znanstveni rad \\ Primljeno: 10. 5. 2020.
}

Ivan LANDRIPET (iD https://orcid.org/0000-0002-6276-9742

Filozofski fakultet Sveučilišta u Zagrebu, Hrvatska ilandrip@ffzg.hr

Goran KOLETIĆ (iD) https://orcid.org/0000-0003-0976-1685 Filozofski fakultet Sveučilišta u Zagrebu, Hrvatska gkoletic@ffzg.hr

Luka JURKOVIĆ (D) https://orcid.org/0000-0003-0407-3832 Filozofski fakultet Sveučilišta u Zagrebu, Hrvatska ljurkovi@ffzg.hr

Siniša ZRINŠČAK (D) https://orcid.org/0000-0003-3542-0585 Pravni fakultet Sveučilišta u Zagrebu, Hrvatska sinisa.zrinscak@pravo.hr

Aleksandar ŠTULHOFER (D) https://orcid.org/0000-0001-5138-3644

Filozofski fakultet Sveučilišta u Zagrebu, Hrvatska astulhof@ffzg.hr

\section{SAŽETAK}

Diljem svijeta vjerske zajednice i laička vjerski orijentirana udruženja potiču vjernike, osobito mlade, na aktivan angažman u promicanju i zaštiti religijskih vrijednosti. $U$ Hrvatskoj se vjerski društveni angažman promovira i prakticira već desetljećima, no taj je iskaz religioznosti ostao posve neistraženim. $U$ svrhu stvaranja pretpostavki za izučavanje raširenosti, oblika, pozadine i učinaka takve vjerske prakse, u radu se predstavlja izrada i metrijska provjera Skale vjerom inspiriranoga društvenog angažmana (VIDA). U kvalitativnome dijelu istraživanja kreirano je 16 indikatora konceptualno predviđenih dimenzija humanitarnoga, evangelizacijskog, građanskog i političkoga društvenog angažmana. Anketni, evaluacijski, dio istraživanja proveden je na slučajnom uzorku mladih u dobi od 18 do 25 godina $(N=552)$, selektiranih iz velikoga nacionalnog internetskog panela. Struktura i spolna invarijatnost VIDA-e provjerena je konfirmacijskom faktorskom analizom, a valjanost njezinim povezivanjem s drugim 
mjerama religioznosti te srodnim stavovskim i vrijednosnim obilježjima. Za cjelinu i podskale VIDA-e analizama je demonstrirana kriterijska, konstruktna i diskriminacijska valjanost, visoka interna konzistentnost, dobro pristajanje latentne strukture podacima te podjednaka primjenjivost na mlade muškarce i žene u Hrvatskoj. Na kraju rada kratko se raspravlja o ograničenjima i mogućnostima uporabe nove mjere.

Ključne riječi: vjerom inspiriran društveni angažman, religioznost, vjerske prakse, konzervativni društveni pokret, mladi

\section{UVOD}

Religioznost u Hrvatskoj zamjetno je porasla početkom tranzicijskog razdoblja, no od početka 21. stoljeća bilježi se njezin blagi, ali sustavan pad, barem u dijelu obilježja kao što je crkvenost, odnosno konfesionalna identifikacija, pohađanje vjerskih obreda te povjerenje u Crkvu i njezinu javnu ulogu (Črpić i Zrinščak, 2010; Baloban, Šimunović i Ježovita, 2019; Nikodem i Zrinščak, 2019a). Većina istraživanja, međutim, ne potvrđuje takav trend za mlade, među kojima je religioznost stabilna (Črpić i Zrinščak, 2010) ili čak u blagom porastu (Marinović Jerolimov i Jokić, 2010; Gvozdanović i dr., 2019). To se tumači dugoročnim učinkom revitalizacije društvene uloge i javne prisutnosti Crkve, uvođenja vjeronauka u škole te sustavne religijske edukacije (Zrinščak, 2001; Marinović Jerolimov, 2002; Zrinščak i dr., 2014). U okviru tih procesa valja posebno istaknuti mogući utjecaj afirmacije ili nastanka novih laičkih crkvenih pokreta te konzervativnih građanskih inicijativa, udruga i političkih stranaka (Marinović Jerolimov i Jokić, 2010), koje su u svojem djelovanju često usmjerene na mlade i poticanje njihova vjerskim vrijednostima orijentiranoga društvenog angažmana (Mihaljević, 2005; Peračković i Mihaljević, 2005; Čepo, 2017; Hodžić i Štulhofer, 2017).

Tema društvenog angažmana utemeljenog u vjeri u Hrvatskoj je empirijski posve neistražena. U ovom se radu predstavlja složeni instrument, Skala vjerom inspiriranoga društvenog angažmana (VIDA), razvijen za potrebe valjanog i pouzdanog mjerenja te teme među mladima. Najprije se opisuje društveni kontekst koji taj fenomen čini aktualnim i akademski relevantnim, a zatim se predstavljaju dosadašnje spoznaje o odnosu religioznosti i društvenog angažmana te strategija izrade i vrednovanja VIDA-e. Nakon opisa metodologije kvalitativnoga (konstrukcijskog) i kvantitativnoga (validacijskog) dijela istraživanja predstavljaju se rezultati provjere latentne strukture, pouzdanosti i valjanosti nove mjere, dok se u raspravi i zaključku primarno razmatraju doseg primjene i ograničenja VIDA-e. 


\subsection{Društveni angažman kao dužnost vjernika? Potreba za mjerenjem religioznosti mladih u vidu vjerom inspiriranoga društvenog angažmana}

Novi su crkveni (eklezijalni) pokreti "vjernički, laički pokreti u Crkvi koji nastaju [...] kao egzistencijalni odgovori na društvenu situaciju, religijske izazove ili eklezijalne okolnosti ili (ne)prilike određenog vremena" (Tadić, 2002: 21). U Hrvatskoj se pojavljuju krajem šezdesetih i početkom sedamdesetih godina 20. stoljeća i "vjernicima (a u hrvatskom je slučaju riječ o vjernicima Katoličke crkve) daju mogućnost praktičnoga vjerničkog življenja, svjedočenja vjere u svakodnevnom životu te promicanja kršćanskoga društvenog i kulturnog vrijednosnog sustava" (Tadić, 2002: 21-22). Primjeri su Pokret fokolara, Mali tečaj (Kursiljo), Karizmatička obnova, Franjevačka mladež, Zajednica bračnih susreta, pokret iz Taizea i niz molitvenih zajednica. Uslijed društveno-političkih okolnosti njihovo djelovanje dolazi u fokus javnosti tek s početkom procesa demokratizacije, a dio se tih organizacija (kao i mnoge novoosnovane) tad usmjerava i na šire društveno djelovanje. To se prije svega odnosi na humanitarni (karitativni) i općekorisni rad kroz aktivnosti poput pomaganja ljudima lošijega imovinskog stanja ili zdravlja, terapijske pomoći stradalnicima Domovinskog rata i zauzimanja za zaštitu okoliša, uz različite oblike evangelizacijskog djelovanja u vidu organiziranja susreta duhovne obnove, molitvenih skupova i hodočašća te promicanja ekumenizma (Mihaljević, 2005; Peračković i Mihaljević, 2005).

Inicijative koje tvore tzv. konzervativni društveni pokret, odnosno građanske i političke organizacije posvećene reformiranju društva u skladu s kršćanskim vrijednostima, u Hrvatskoj se pak pojavljuju i afirmiraju znatno kasnije od laičkih crkvenih pokreta (prvom takvom organiziranom inicijativom smatra se udruga Glas roditelja za djecu osnovana 2006. s ciljem sprečavanja uvođenju spolnog odgoja u školski kurikulum; Petričušić, Čehulić i Čepo, 2017), ali u javnom djelovanju nastupaju mnogo izravnije i učinkovitije od njih oslanjajući se na zagovaranje izravne demokracije, na sekularizirani diskurs, uporabu suvremenih medija, kolektivno djelovanje i mobilizaciju javnosti (Hodžić i Štulhofer, 2017; Čepo, 2017; Vučković Juroš, Dobrotić i Flego, 2020). Uz nekoliko političkih inicijativa i manjih stranaka, riječ je o većem broju umreženih organizacija civilnog društva koje su sudjelovale u organiziranju niza masovnih okupljanja i prosvjeda, skupnih molitvi na javnim prostorima, prikupljanja potpisa za nacionalne referendume, djelovanju prema tijelima zakonodavne vlasti i drugim aktivnostima usmjerenim na (re)afirmiranje tradicionalnih vrijednosti obitelji i spolnih/rodnih odnosa, ograničavanje seksualnih prava, prava seksualnih manjina i prava na pobačaj, ali i nekih političkih prava nacionalnih manjina te na reformiranje izbornog sustava. Takav organizirani angažman vjernika u 
društvu i poticanje drugih vjernika na društveni angažman nije hrvatski specifikum ni u ciljevima ni načinima njihova ostvarivanja (usp. De Hart, Dekker i Halman, 2013; Paternotte i Kuhar, 2017).

Iz perspektive vjerskog učenja, u slučaju Katoličke crkve, a osobito njezina socijalnog nauka, društveni se angažman može smatrati očekivanjem od vjernika, gotovo vjerničkom dužnošću, ne samo u tradicionalnom, evangelizacijskom i humanitarno-karitativnom, volonterskom, obliku (Črpić, 2002), nego i onom civilno-političkom, koji se osobito aktualizira u vrijednosno pluralnim društvima (Garelli, 2013). Prema Kompendiju socijalnog nauka Crkve, formiranje vjernika-laika odvija se posredstvom katoličkih odgojnih ustanova na dvjema razinama. Prva je osposobljavanje za osobni društveni angažman, "za djelotvorno sučeljavanje sa svakodnevnim zadaćama na kulturalnom, društvenom, gospodarskom i političkom području, razvijajući u vjernicima smisao za dužnost koju treba potvrditi u služenju općem dobru", dok se druga razina odnosi na "formacije političke svijesti da se kršćanski laici pripreme na obnašanje političke vlasti” (Baloban, 2012: 1026). Slični pozivi za javni i politički angažman vjernika dolaze i iz drugih izvora unutar Crkve (npr., Ratzinger, 2003; Garelli, 2013) te su svojstveni i drugim kršćanskim crkvama (Campbell, 2004; Son i Wilson, 2012; Ray, 2017; Polson, 2018).

Volonterski društveni angažman potaknut vjerom tako se može promatrati kao iskaz vjere, ali i legitimni oblik, odnosno indikator religioznosti (usp. Črpić, 2002: 426). No, u Hrvatskoj ne postoje empirijske studije usmjerene na fenomen društvenog angažmana utemeljenog u religioznosti (usp. sljedeću cjelinu rada), premda je religioznost jedna od najistraživanijih tema u okviru hrvatske sociologije i društvenih znanosti općenito, a istodobno su aktivnosti konzervativnih inicijativa usmjerene na poticanje vjernika na građansko-politički angažman u zadnjih desetak godina intenzivne, javno vrlo prepoznatljive, pa i učinkovite. Ne postoje ni instrumenti primjereni mjerenju toga složenog predmeta istraživanja kakvi bi, uz prethodno spomenutu svrhu, mogli biti od velike koristi u rasvjetljavanju još dva aktualna fenomena vezana uz religioznost u hrvatskom društvu. Najprije, riječ je o trendu polarizacije vjerničke populacije na skupinu distancirane osobne i osobito institucionalne religioznosti te na skupinu postojane i intenzivne osobne $\mathrm{i}$ institucionalne religioznosti, za koju se procjenjuje da obuhvaća i do četvrtine stanovništva i uz koju se veže osjetan potencijal za vjerom inspirirano društveno djelovanje (Črpić i Zrinščak, 2010; Nikodem i Zrinščak, 2019a, 2019b). Potom, intenzivna je religioznost povezana $s$ desnom političkom orijentacijom, a ta se povezanost također intenzivira u zadnjih desetak godina (Nikodem i Zrinščak, 2019a, 2019b). 


\subsection{Odnos religioznosti i društvenog angažmana: postojeće spoznaje, načini mjerenja i cilj ovog istraživanja}

Društveni angažman kojem bi mobilizacijska osnova bila religioznost u Hrvatskoj empirijski je neistraženo područje. Postoji samo nekoliko studija u kojima je primijenjen manji broj indikatora parcijalno usmjerenih na neke od ranije navedene aspekte tog predmeta mjerenja, uglavnom humanitarnog i evangelizacijskoga, i to samo na razini izražavanja spremnosti na angažman ili podrške angažmanu, ne i osobnog iskustva. Tako je u istraživanju o spremnosti vjernika za suradnju u životu Katoličke crkve mjerena spremnost za karitativni rad, rješavanje materijalnih problema u župi te vjerski i etičko-moralni odgoj mladih (npr., Baloban, 2011, 2012; Črpić i Mravunac, 2011), a u istraživanju o ulozi vjere i Crkve u procesima oprosta i pomirenja slaganje s tvrdnjama da bi "pravi kršćani" trebali pomagati siromašnima, davati krv, širiti ekumenizam, djelovati u volonterskim katoličkim organizacijama te glasati za kršćanske, odnosno nacionalno obojene, stranke (Vučković i Črpić, 2007).

U Hrvatskoj nisu dostupna ni istraživanja koja bi religioznost dovela u vezu s iskustvom općega društvenog angažmana - takvog koji zahvaća širi, i posve sekularni, raspon aktivnosti. Istraživanja najbliža tome nacionalna su istraživanja mladih u kojima je ispitivana veza između religioznosti i spremnosti na humanitarni, građanski i politički vid društvenog angažmana (llišin, 2017). Nasuprot tomu, odnos religioznosti i osobnog iskustva općega društvenog angažmana u međunarodnim je okvirima temeljito istražen, u zadnje vrijeme s osobitim naglaskom na mlade (Veeh i dr., 2019). Pozadina toga višedesetljetnog istraživačkog interesa je dvojaka. Ponajprije, društveni se angažman uvažava kao važan oblik odgovornog i produktivnog građanstva koji se pozitivno odražava na osjećaj povjerenja, ispunjenosti i svrhe te pripadanja zajednici (Droege i Ferrari, 2012). Potom, na Zapadu su razine društvenog angažmana već desetljećima u padu. Autori poput Roberta Bellaha u osamdesetim i Roberta Putnama u devedesetim godinama 20. stoljeća odgovor na taj društveni izazov dijelom vide u vjerskim organizacijama zbog prosocijalnih vrijednosti koje zagovaraju, ali i zbog efikasnosti u mobiliziranju članova svoje kongregacije uslijed organizacijskih vještina koje posjeduju i društvenih mreža koje generiraju (Driskell, Lyon i Embry, 2008). To su viđenja koja u nešto rudimentarnijem obliku uostalom potječu još od de Tocquevilleova promišljanja povoljnog utjecaja religijskih organizacija na demokratičnost američkoga političkog sustava (Ray, 2017).

Nalazi empirijskih provjera takvih pretpostavki gotovo bez iznimke potvrđuju snažnu pozitivnu vezu religioznosti i općega društvenog angažmana (Driskell i dr., 2008; Polson, 2018). Pritom već spomenuti (posredujući) učinak religijskih 
društvenih mreža, odnosno religijskoga društvenog kapitala, predstavlja jednu od dviju temeljnih teorijskih perspektiva kojima se taj odnos tumači, a učinak prosocijalnih vrijednosti vjerskih učenja te religijskog viđenja društvene pravednosti i ispravnog djelovanja onu drugu, teoriju perspektive vrijednosne orijentacije (Cnaan i dr., 2012; Yeung, 2017). Važno je istaknuti i da se religiozni građani u odnosu na nereligiozne volonterski ne angažiraju češće samo oko vjerskih nego i sekularnih društvenih inicijativa (osobito u slučaju katolika u odnosu na druge kršćanske denominacije i vjernike-nekršćane), što se tumači učinkom prelijevanja religijskoga društvenog kapitala, vrijednosti i organizacijskih vještina iz sfere vjerskoga u sferu općega društvenog djelovanja (Ruiter i de Graaf, 2006).

Ipak, društveni kapital kojim religioznost pospješuje opći društveni angažman nije primarno premošćujućega nego povezujućeg oblika (odvija se unutar skupina koje su konfesionalno homogene) te se korelati općega u odnosu na specifično vjerski društveni angažman razlikuju (opći je angažman, za razliku od vjerskoga, povezan, primjerice, s individualnom autonomijom i uopćenim povjerenjem) - što sugerira različit karakter tih dvaju oblika društvenog angažmana (Storm, 2015). Usto se pokazuje da je religioznost, uslijed prosocijalnih vrijednosti religijskih učenja te naglaska na društvenoj pravednosti i ispravnosti, u bliskijoj vezi s nekim oblicima općega društvenog angažmana kao što su humanitarni i civilno-politički, a u slabijoj ili ni u kakvoj vezi s oblicima poput rekreacijskih i kulturnih (Yeung, 2017). Drugim riječima, premda je opći društveni angažman snažno povezan s religioznošću i njezin je čest izraz, on nipošto nije oblik religioznosti, odnosno njezin specifični indikator. Zbog toga opći društveni angažman ne može poslužiti ni u mjerenju vjerski motiviranoga društvenog angažmana. Međutim, temeljit pregled dostupne međunarodne literature upućuje na neočekivani zaključak da složeni instrumenti namijenjeni mjerenju zastupljenosti i učinaka specifično vjerski potaknutoga društvenog angažmana još nisu razvijeni. ${ }^{1}$

Cilj našeg istraživanja stoga je bio izraditi mjeru vjerom inspiriranoga društvenog angažmana, koja će svojim sadržajnim opsegom i jezičnim obilježjima odgovarati specifičnostima hrvatskog društva te će valjano i pouzdano mjeriti taj akademski i društveno relevantan aspekt religioznosti. Primjenu takvog instrumenta vidimo u širokom rasponu društvenih istraživanja usmjerenih na izučavanje religioznosti ili

Za međunarodnu su literaturu pretraženi naslovi, sažeci i ključne riječi izvora dostupnih u citatnim bazama, odnosno zbirkama, Science Direct, Scopus i Web of Science po pojmovima religion and civic engagement / activism te measure / scale / index / inventory / questionnaire of religious I religion-motivated / religion-basedl religion-inspired / faith activism / engagement. Za radove (primarno) hrvatskih autora dodatno su pretraženi izvori koji se navode na portalu Hrčak i u mrežnoj bibliografiji CROSBI, po prethodno navedenim pojmovima na engleskom jeziku te po njihovim prijevodima na hrvatski jezik. Izvore se pretraživalo u rujnu i listopadu 2019. 
društvenih fenomena koji se dovode u vezu s religioznošću i vjerskim praksama mladih.

\section{STRATEGIJA KONSTRUKCIJE I VALIDACIJE VIDA-e}

Istraživanja društvenog angažmana obilježava nedostatak standardne, općeprihvaćene, definicije tog pojma (Driskell i dr., 2008; Veeh i dr., 2019). Uvažavajući temeljna zajednička obilježja raznih korištenih određivanja i načina mjerenja tog koncepta u svojem općem obliku, koji su u osnovnim crtama predstavljeni u prethodnim dijelovima rada iz inozemnih i domaćih izvora, u ovom istraživanju vjerom inspiriran društveni angažman odredili smo kao volontersko, dobrovoljno i neplaćeno, djelovanje u javnoj sferi koje je utemeljeno u vrijednostima vlastite vjere $i$ njima potaknuto, a iskazuje se u četirima temeljnim oblicima: humanitarnom ( $\mathrm{rad} \mathrm{s}$ potrebitima i za potrebite), evangelizacijskom (promoviranje i zagovaranje religijskih vrijednosti među kršćanima i nekršćanima), građanskom (sudjelovanje u radu ili aktivnostima građanskih inicijativa kojima se promoviraju religijske vrijednosti) i političkom (podržavanje ili sudjelovanje u radu političkih stranaka i inicijativa čiji se programi temelje na religijskim vrijednostima). Da podsjetimo, humanitarna, građanska i politička dimenzija općeg karaktera standardno su prisutne u mjerenju općeg društvenog angažmana te su se - za razliku od dimenzija poput rekreacijskih i kulturno-umjetničkih - u dosadašnjim studijama pokazale pozitivno povezane s religioznošću (Driskell i dr., 2008; Droege i Ferrari, 2012; Cnaan i dr., 2012; Yeung, 2017; Veeh i dr., 2019). Uz dodatak evangelizacije, kao inherentno vjerskog oblika društvenog angažmana (Veeh i dr, 2019), opravdanost koncipiranja tih četiriju dimenzija kao aspekata vjerskoga društvenog angažmana potvrđuju i oblici djelovanja koje u Hrvatskoj zagovaraju laički crkveni pokreti (primarno humanitarne i evangelizacijske aktivnosti) te konzervativne građanske i političke inicijative (primarno građanske i političke aktivnosti) (Mihaljević, 2005; Peračković i Mihaljević, 2005; Petričušić i dr., 2017; Čepo, 2017). Takvu konceptualizaciju potvrđuju i poticaji na specifične oblike angažmana koji vjernicima upućuju vjerske organizacije, odnosno službeno vjersko učenje (Črpić, 2002; Garelli, 2013; Campbell, 2004).

Premda iz navedenih izvora proizlaze i brojni sadržajni momenti vezani uz svaku od četiriju predviđenih dimenzija VIDA-e, pri njihovoj operacionalizaciji oslonili smo se na induktivni pristup. Osim što postojeći instrumenti nisu bili namijenjeni ciljanom mjerenju vjerom inspiriranoga društvenog angažmana, u razgovorima s religioznim mladim ljudima iz ciljane populacije željeli smo, naime, zabilježiti cijeli raspon iskustava koja su oni osobno ili njihovi bliski poznanici imali s tim oblikom društvenog angažmana vjerom kako bi VIDA sadržajnim opsegom i jezičnim obilježjima što bolje odgovarala specifičnostima hrvatskog društva. Više o ishodu 
tog postupka konstrukcije indikatora te više o analitičkoj strategiji provjere latentne strukture i pouzdanosti VIDA-e navodi se u metodološkoj cjelini rada, a u nastavku ove cjeline kratko se još nudi konceptualna osnova odabranog načina provjere kriterijske, konstruktne i diskriminacijske valjanosti VIDA-e.

Provjera kriterijske valjanosti zamišljena je testiranjem pretpostavke o pozitivnoj povezanosti VIDA-e s dvjema postojećim mjerama religioznosti koje su figurirale kao vanjski kriteriji istovjetnog predmeta mjerenja. Prva mjera, učestalost pohađanja vjerskih obrada, ritualna je, participacijska, dimenzija religioznosti i jedna od najkorištenijih općih mjera religioznosti u hrvatskim i međunarodnim okvirima (Bezinović, Marinović-Bobinac i Marinović Jerolimov, 2005; Yeung, 2017). Učestalo se koristi i u istraživanjima odnosa religioznost i sklonosti volontiranju u različitim aspektima društvenog angažmana, u kojima se tipično bilježi pozitivna korelacija tih obilježja (Driskell i dr., 2008; Polson, 2018), uključujući istraživanja na uzorcima mladih (Gibson, 2008). Druga korištena mjera, intrinzična religioznost, predstavlja Allportov koncept "zrele" religioznosti obilježene njegovanjem i prakticiranjem vjere u svakodnevnom životu (Darvyri i dr., 2014). Kako je već istaknuto, društvene i doktrinarne vrijednosti vjere potiču, pa i obavezuju, vjernike na altruistično i društveno-političko djelovanje (Son i Wilson, 2012), što je i potvrđeno dosadašnjim istraživanjima i metaanalizama (Trimble, 1997; Mencken i Fitz, 2013).

Provjera konstruktne valjanosti, u obliku konvergentne valjanosti, zamišljena je testiranjem pretpostavke o pozitivnoj povezanosti VIDA-e s postojećim mjerama triju obilježja za koja se teorijski uspostavlja pozitivan odnos s religioznošću: klerikalizma, rodnog tradicionalizma i seksualnog konzervativizma. Klerikalizam je politički koncept kojim se zagovara veći utjecaj Crkve na politička zbivanja, odnosno podrazumijeva da bi svećenstvo trebalo imati političke predstavnike u zastupničkim tijelima vlasti te da bi se zakoni trebali temeljiti na naučavanju Crkve (Čulig, 2004; napominjemo da takva konceptualizacija kombinira dva različita utjecaja $\mathrm{Cr}$ kve na društvo - izravnu participacija svećenstva u vlasti te rukovođenje Crkvenim učenjem u državnim politikama - čija bi se kompatibilnost trebala dodatno razjasniti). Pozitivan odnos klerikalizma i religioznosti konzistentno se empirijski potvrđuje (npr., Čulig, 2004; Čulig, Klasnić i Jakšić, 2011), kao i pozitivan odnos, uglavnom utvrđen u populacijama mladih, religioznosti s tradicionalnim viđenjem rodnih uloga u privatnoj i javnoj sferi (Štimac Radin, 2014; Sekulić i Šporer, 2006; Šram, 2008; Jugović i Ančić, 2013) te s konzervativizmom u pogledu seksualnih prava i sloboda (Bouillet, 2014; Gvozdanović i dr., 2019; Marinović Jerolimov i Ančić, 2014; Marinović Jerolimov i Jokić, 2010; Jugović i Ančić, 2013). Konceptualno, polazi se od pretpostavke da je religioznost dio konzervativnoga vrijednosnog kompleksa i tako povezana s drugim obilježjima konzervativne orijentacije, uključujući onu rodnu i seksualnu (Sekulić i Šporer, 2006; Sekulić, 2011). 
Napokon, provjera diskriminacijske valjanosti zamišljena je testiranjem pretpostavke o sposobnosti VIDA-e da razlikuje skupinu sudionika istraživanja koji su striktno odgajani u vjerskom duhu od skupine onih koji nisu. Naime, ranije spomenuta teorija perspektive vrijednosne orijentacije, koja se često koristi u konceptualiziranju odnosa religioznosti i društvenog angažmana (Yeung, 2017), vjersku socijalizaciju drži važnom pretpostavkom razvoja vjerske vrijednosne orijentacije zbog izloženosti religijskim vrijednostima i njihova usvajanja u ranom, formativnom, razdoblju. Pozitivan odnos religijske socijalizacije i vjerske vrijednosne orijentacije potvrđen je u nizu istraživanja (usp. Vermeer i Scheepers, 2012; 2019).

\section{METODOLOGIJA}

\subsection{Sudionici i provedba validacijskog (anketnog) dijela istraživanja}

U glavnom, kvantitativnom, dijelu istraživanja sudjelovale su 552 osobe starosti između 18 i 25 godina. $^{2}$ Sociodemografska obilježja sudionika prikazana su u Tablici 1. Podaci su prikupljeni tijekom siječnja i veljače 2020. godine u internetskom panelu komercijalne agencije za tržišna istraživanja. Sudionici su u panel većinski regrutirani iz agencijskih nacionalnoreprezentativnih istraživanja, čime se osigurava regionalna pokrivenost. Iz postojeće baze od 15000 panelista agencija kreira kvotne uzorke s obzirom na dob, spol, regiju i veličinu naselja. Sudionici su potom slučajnim odabirom kontaktirani za sudjelovanje u istraživanju. lako sam panel nije reprezentativan za populaciju Hrvatske, uključujući obilježje religioznosti, kvotni pristup uzorkovanju omogućuje poklapanje sa strukturom ciljane nacionalne populacije. Provedbu svih dionica istraživanja odobrilo je Povjerenstvo za prosudbu etičnosti istraživanja Odsjeka za sociologiju Filozofskog fakulteta Sveučilišta u Zagrebu.

2 Taj dobni raspon predstavlja jedno u nizu mogućih određenja populacijskog segmenta "mladih". Odabran je budući da se uobičajeno koristi za definiranje populacije mladih na prijelazu iz adolescencije u odraslu dob (engl. emerging adults; usp. Veeh i dr., 2019), a zakonska punoljetnost, odnosno 18 navršenih godina, kao donja granica raspona omogućuje još i mjerenje punog opsega društvenog angažmana, poput političkog djelovanja. 
Tablica 1. Sociodemografska obilježja sudionika $(N=552)$

\begin{tabular}{lc}
\hline & $N(\%)$ \\
\hline Spol & \\
Muški & $279(50,5)$ \\
Ženski & $273(49,5)$ \\
\hline Obrazovanje & \\
Srednja škola ili niže & $385(69,7)$ \\
Više od srednje škole & $167(30,3)$ \\
\hline Regija & \\
Zagreb i okolica & $145(26,3)$ \\
Sjeverna Hrvatska & $104(18,8)$ \\
Slavonija & $110(19,9)$ \\
Lika i Banovina & $36(6,5)$ \\
Istra, Primorje i Gorski kotar & $50(9,1)$ \\
Dalmacija & $107(19,4)$ \\
\hline Veličina naselja & \\
Do 2000 stanovnika & $143(25,9)$ \\
2001-10000 stanovnika & $93(16,8)$ \\
10001 -80000 stanovnika & $106(19,2)$ \\
80001 i više stanovnika & $210(38,0)$ \\
\hline Tip naselja & $143(25,9)$ \\
Selo & $409(74,1)$ \\
\hline Grad & \\
\hline Dob & \\
\hline & \\
\hline & \\
\hline & \\
\hline
\end{tabular}

3.2. Sudionici, provedba i ishod konstrukcijskog (kvalitativnog) dijela istraživanja

Prije kvantitativne dionice istraživanje, tijekom studenog i prosinca 2019. provedeno je pripremno kvalitativno istraživanje u svrhu stvaranja inventara ponašanja relevantnih za VIDA-u. Elektronička pisma s opisom istraživanja poslana su vjerskim organizacijama orijentiranim na mlade koje djeluju na području grada Zagreba (adresirali smo pet organizacija) te nekolicini nastavnika s Katoličkog bogoslovnog fakulteta u Zagrebu i Hrvatskog katoličkog sveučilišta, s molbom da ih proslijede svojim članovima odgovarajuće dobi, odnosno svojim studentima. Pozitivan odgovor primili smo samo od malog broja kontaktiranih te smo na taj način uspjeli prove- 
sti jedan skupni intervju (s troje sudionika) i pet individualnih intervjua. Zbog slabog odaziva, regrutacija je nastavljena osobnim kontaktima te uz pomoć udruge koja okuplja religiozne studente Filozofskog fakulteta Sveučilišta u Zagrebu, zahvaljujući čemu je provedeno dodatnih pet individualnih intervjua. Ukupno se odazvalo 11 sudionica i 2 sudionika u dobi između 18 i 26 godina, od kojih je osmero bilo uključeno u rad svoje župe.

Intervjui su bili nestrukturirani, odnosno vodič za njihovo provođenje nije predviđao širi popis tema koje je tijekom intervjua valjalo osloviti. Intervjueri, odnosno moderatori (drugi i treći autor ovog rada), u uvodnom su obraćanju sudionicima tek naveli da se u istraživanju žele zabilježiti iskustva sa svim aktivnostima obavljanima bez novčane naknade s ciljem da se pomogne drugim ljudima ili utječe na društvene promjene, a da je temeljni poticaj za takav angažman pritom dolazio iz vjerskih uvjerenja osobe i vrijednosti njezine vjere. Kako bi se sudionicima ilustriralo na što se sve pritom misli, oslovljene su četiri osnovne skupine aktivnosti sukladno četirima ranije konceptualiziranim dimenzijama VIDA-e: humanitarni rad (bez navođenja određenja ili dodatnog opisa), promoviranje religijskih vrijednosti (kao primjer je naveden angažman na širenju vjerskih sadržaja u izravnom kontaktu s drugim ljudima ili putem internetskih sadržaja poput društvenih mreža), zatim građanski angažman (uz pojašnjenja da se to može odnositi na sudjelovanje u radu ili aktivnostima inicijativa i udruga koje promoviraju religijske vrijednosti, poput sudjelovanja u javnim prosvjedima i prikupljanju potpisa građana) te politički angažman (naveden je primjer glasanja na izborima i rada u kampanji za političku stranku ili kandidata čiji su programi usklađeni s vjerskim vrijednostima). Istaknuto je i da mogu navesti iskustva s volonterskim i vjerom inspiriranim aktivnostima koje nisu obuhvaćene tim četirima širim skupinama. Sudionicima su također zamoljeni da navedu sva takva iskustva koja su stekli oni osobno, ali i ona za koja znaju da su ih stekli njima osobno poznati mladi ljudi iz Hrvatske (rođaci, prijatelji, osobe uključene u rad njihove župe i slično). Time se nastojao prikupiti što širi raspon iskustava vjerom inspiriranoga društvenog angažmana među mladima u Hrvatskoj u okolnostima kad bilježenje isključivo vlastitih iskustava nije bilo nužno u analitičkom smislu.

Razgovori su tonski snimani uz izričitu privolu sudionika prije početka individualnog ili skupnog intervjua. S obzirom na ciljeve ove analize, snimljeni materijal kasnije nije transkribiran u doslovnom, ekstenzivnom, obliku, nego su kod preslušavanja snimki detektirane i bilježene samo relevantne aktivnosti koje su sudionici navodili. Snimljeni zapisi potom su obrisani s uređaja za snimanje i s računala na koja su bili pohranjeni.

Individualnim i skupnim intervjuima prikupljeni su iskazi o više od stotinu aktivnosti koje su okvirno bile vezane uz humanitarni i evangelizacijski te u manjoj 
mjeri građanski i najmanje politički vjerom inspiriran društveni angažman (primjerice, pomaganje u pučkoj kuhinji, sudjelovanje u organizaciji ekumenskog susreta, pozivanje poznanika putem društvenih mreža da se pridruže Hodu za život, rad na instagramskoj stranici koja poziva mlade vjernike da izađu na izbore, prosvjede i slično). Sudionici nisu spontano oslovili aktivnosti koje bi izlazile iz th okvira. Objedinjavanjem sadržajno preklapajućih ili vrlo bliskih aktivnosti (primjerice, administriranje Facebook grupe posvećene mladim vjernicima na kojoj se objavljuju sadržaji poput duhovnih citata te pozivnica na događaje duhovne tematike i korištenje Instagrama za objavljivanje sadržaja duhovne tematike poput citata i poruka) ostvarilo se između 40 i 50 indikatora VIDA-e. Osim što bi instrument u tom, vrlo obimnom, obliku bio nepraktičan za upotrebu u većini istraživanja koja usko ne ciljaju tu tematiku, obilježavao bi ga znatan nerazmjer u količini čestica u dimenzijama humanitarnog i evangelizacijskog nasuprot građanskog i političkog angažmana. Još važnije, znatan bi dio aktivnosti bilježio vrlo male ili nikakve frekvencije $u$ istraživanjima usmjerenim na opće populacije mladih, čemu je VIDA primarno i namijenjena, pa bi upotrebljivost rezultata bila upitna ili bi istraživači morali naknadno objedinjavati pojedine aktivnosti po empirijskom kriteriju. Kako bi se to izbjeglo, autori su dodatno objedinili sadržajno bliske oblike angažmana u indikatore šireg obuhvata i općenitijeg sadržaja ciljnih iskustava i praksi uz koje su, u većini slučajeva, u zagradi pruženi primjeri aktivnosti koje ona obuhvaćaju (na primjer, "Rad za potrebite (rad u pučkoj kuhinji, obavljanje poslova u prihvatilištu, Caritasu, odlazak u nabavku za susjede i slično).", "Sudjelovanje u radu građanskih udruga i inicijativa koje promoviraju vrijednosti moje vjere (osmišljanje programa aktivnosti, prikupljanje sredstava, izrada i dijeljenje promotivnih materijala, prikupljanje potpisa za referendume, pomoć u organizaciji javnih okupljanja, pozivanje drugih na sudjelovanje u javnim aktivnostima i slično)."). Za svaku konceptualno predviđenu dimenziju vjerom inspiriranoga društvenog angažmana tako je konstruiran inventar od po četiri čestice. Za ljestvicu procjene koja se veže uz svaku česticu VIDA-e predviđeno je da sadržava sljedeće odgovore: 0 = nisam se bavio/la, 1 = jednom, 2 = dva puta, 3 = tri puta ili više. Te su kategorije također osmišljene na temelju iskaza sudionika o učestalosti angažiranja u pojedinim aktivnostima, uzimajući u obzir da će se VIDA po pravilu koristiti u istraživanjima u kojima će i među mladim vjernicima biti manja učestalost takva angažmana.

Napokon, u svrhu dodatne provjere grupiranja pojedinih aktivnosti u pojedine indikatore te jezične i sadržajne razumljivosti, potku i čestice iz VIDA-e na kraju su analizirali i komentirali studenti Filozofskog fakulteta i Prirodoslovno-matematičkog fakulteta Sveučilišta u Zagrebu (prigodni uzorak od 18 sudionica i sudionika). Pritom je sugerirano i uvaženo nekoliko sitnijih izmjena kojima su se formulacije pojednostavile u tri čestice i u potki instrumenta, bez zadiranja u njihov predviđeni sadržaj. Konačan popis svih čestica i potka VIDA-e predstavljeni su Tablici 2. 
Tablica 2. Deskriptivna obilježja čestica koja tvore VIDA-u

\section{Humanitarni angažman}

1. Materijalna pomoć u vidu doniranja novca ili stvari potrebitim pojedincima ili dobrotvornim organizacijama (Caritas, Unicef i slično).

2. Rad s potrebitima (stariji, djeca, beskućnici, ovisnici, bolesni, izbjeglice i slično).

3. Rad za potrebite (rad u pučkoj kuhinji, obavljanje poslova u prihvatilištu, Caritasu, odlazak u nabavku za susjede i slično).

4. Djelovanje za opću korist: davanje krvi, davanje instrukcija učenicima ili studentima, sudjelovanje u radionicama o ovisnosti, nasilju, zaštiti okoliša i slično.

\section{Evangelizacijski angažman}

5. Sudjelovanje u aktivnostima duhovne tematike (hodočašća, duhovni susreti, obnove, kulturno-umjetničke vjerske aktivnosti i slično).

6. Sudjelovanje u edukacijskim sadržajima temeljenim na vjerskim vrijednostima (predavanja ili radionice o poduzetništvu, spolnost i vezama, obitelji, aktivnostima mladih u slobodno vrijeme, ekološkim temama i slično) u cilju osnaživanja uloge vjere u životu mladih ljudi.

7. Sudjelovanje u organiziranju aktivnosti duhovne tematike ili edukacijskih sadržaja temeljenih na vjerskim vrijednostima.

8. Objavljivanje sadržaja duhovne tematike na internetu ili drugim medijima (profili i grupe na društvenim mrežama, blogovi, vlogovi, webstranice, televizijske i radijske emisije i slično).

\begin{tabular}{|c|c|c|c|c|c|}
\hline 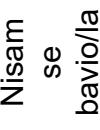 & $\begin{array}{l}\varepsilon \\
\text { O } \\
\text { O } \\
\stackrel{D}{J}\end{array}$ & 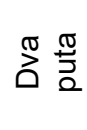 & 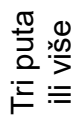 & $M$ & $S D$ \\
\hline $20 \%$ & $21 \%$ & $19 \%$ & $40 \%$ & 1,79 & 1,17 \\
\hline $54 \%$ & $18 \%$ & $13 \%$ & $15 \%$ & 0,89 & 1,12 \\
\hline $64 \%$ & $16 \%$ & $10 \%$ & $9 \%$ & 0,63 & 0,98 \\
\hline $30 \%$ & $21 \%$ & $17 \%$ & $32 \%$ & 1,51 & 1,22 \\
\hline $48 \%$ & $19 \%$ & $15 \%$ & $18 \%$ & 1,04 & 1,17 \\
\hline $63 \%$ & $19 \%$ & $6 \%$ & $12 \%$ & 0,66 & 1,02 \\
\hline $73 \%$ & $16 \%$ & $6 \%$ & $5 \%$ & 0,44 & 0,83 \\
\hline $79 \%$ & $10 \%$ & $7 \%$ & $4 \%$ & 0,37 & 0,79 \\
\hline
\end{tabular}




\begin{tabular}{|c|c|c|c|c|c|c|}
\hline & 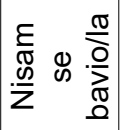 & $\begin{array}{l}\varepsilon \\
\stackrel{\varepsilon}{O} \\
\frac{c}{0} \\
\stackrel{\varrho}{\rho}\end{array}$ & 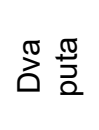 & 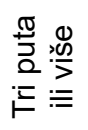 & M & $S D$ \\
\hline \multicolumn{7}{|l|}{ Građanski (civilni) angažman } \\
\hline $\begin{array}{l}\text { 9. Sudjelovanje u radu građanskih udruga i } \\
\text { inicijativa koje promoviraju vrijednosti moje } \\
\text { vjere (osmišljanje programa aktivnosti, } \\
\text { prikupljanje sredstava, izrada i dijeljenje } \\
\text { promotivnih materijala, prikupljanje potpisa } \\
\text { za referendume, pomoć u organizaciji javnih } \\
\text { okupljanja, pozivanje drugih na sudjelovanje u } \\
\text { javnim aktivnostima i slično). }\end{array}$ & $76 \%$ & $12 \%$ & $8 \%$ & $4 \%$ & 0,39 & 0,79 \\
\hline $\begin{array}{l}\text { 10. Uključivanje u javne aktivnosti građanskih } \\
\text { udruga i inicijativa koje promoviraju } \\
\text { vrijednosti moje vjere (potpisivanje peticija, } \\
\text { odlazak na javna okupljanja ili prosvjede i } \\
\text { slično). }\end{array}$ & $74 \%$ & $13 \%$ & $8 \%$ & $5 \%$ & 0,45 & 0,86 \\
\hline $\begin{array}{l}\text { 11. Samoinicijativni angažman u promicanju } \\
\text { vrijednosti moje vjere u društvu (npr. pisanje } \\
\text { prosvjednih poruka medijima ili tijelima vlasti, } \\
\text { pokretanje inicijativa ili okupljanja i slično). }\end{array}$ & $84 \%$ & $8 \%$ & $5 \%$ & $3 \%$ & 0,27 & 0,68 \\
\hline $\begin{array}{l}\text { 12. Doniranje vlastitih sredstava građanskim } \\
\text { udrugama i inicijativama koje promoviraju } \\
\text { vrijednosti moje vjere. }\end{array}$ & $73 \%$ & $13 \%$ & $8 \%$ & $6 \%$ & 0,47 & 0,88 \\
\hline \multicolumn{7}{|l|}{ Politički angažman } \\
\hline $\begin{array}{l}\text { 13. Angažman u političkim strankama ili } \\
\text { inicijativama čiji se program temelji na } \\
\text { vrijednostima moje vjere (članstvo u } \\
\text { strankama, kandidiranje na listama, rad u } \\
\text { stranačkoj mladeži i slično). }\end{array}$ & $82 \%$ & $9 \%$ & $5 \%$ & $4 \%$ & 0,31 & 0,75 \\
\hline $\begin{array}{l}\text { 14. Glasanje na izborima za kandidata, inicijativu } \\
\text { ili političku stranku čiji se program temelji na } \\
\text { vrijednostima moje vjere. }\end{array}$ & $61 \%$ & $20 \%$ & $10 \%$ & $9 \%$ & 0,68 & 0,99 \\
\hline $\begin{array}{l}\text { 15. Poticanje drugih, u osobnom kontaktu ili } \\
\text { putem društvenih mreža, da na izborima } \\
\text { glasaju za kandidata, inicijativu ili } \\
\text { političku stranku čiji se program temelji na } \\
\text { vrijednostima moje vjere. }\end{array}$ & $78 \%$ & $10 \%$ & $7 \%$ & $5 \%$ & 0,38 & 0,81 \\
\hline $\begin{array}{l}\text { 16. Doniranje vlastitih sredstava kandidatima, } \\
\text { inicijativama ili političkim strankama koje } \\
\text { promoviraju vrijednosti moje vjere. }\end{array}$ & $84 \%$ & $9 \%$ & $4 \%$ & $3 \%$ & 0,25 & 0,66 \\
\hline
\end{tabular}

Napomena: potka skale glasi "Inspirirani vrijednostima svoje vjere, neki ljudi dio svojega slobodnog vremena provode volontirajući, odnosno radeći bez financijske naknade kako bi pomogli drugim ljudima ili utjecali na društvene promjene. Molimo Vas da uz svaku navedenu volontersku aktivnost označite jeste li se dosad njome bavili." 


\subsection{Validacijski mjerni instrumenti}

Participacijska religioznost mjerena je uobičajenim indikatorom učestalosti odlazaka na vjerske obrede izuzmu li se vjenčanja, pogrebi i krštenja s pridruženom šestostupanjskom ljestvicom odgovora (od $1=$ nikada, do $6=$ gotovo svakodnevno) i dodatnom opcijom "nisam vjernik/ca". Adaptiranu mjeru intrinzične religioznosti (Darvyri i dr., 2014) činile su četiri čestice (npr. "Čitanje vjerske literature me ispunjava"; "Često osjećam Božje prisustvo u svome životu"). Korištena je procjena od pet stupnjeva ( 1 = uopće se ne odnosi na mene, $5=$ u potpunosti se odnosi na mene). Teorijski raspon kompozitne mjere iznosio je $4-20$ (viši rezultat označavao je višu razinu intrinzične religioznosti), a njezina pouzdanost bila je vrlo zadovoljavajuća (Cronbachov $\alpha=0,91$ ).

Obiteljski odgoj u vjerskom duhu mjeren je jednim pitanjem. Mogući odgovori bili su: 1 = ne, 2 = da, ali ne striktno i $3=$ da, od mene se tražilo da poštujem i provodim vjerska načela.

Klerikalizam je mjeren validiranom skalom (Čulig, Kufrin i Landripet, 2007), koja sadržava četiri čestice (npr. "Zakoni bi se trebali temeljiti na naučavanju Crkve"; "Katolička Crkva jedini je istinski moralni autoritet u ovoj zemlji"). Odgovori su bilježeni na skali slaganja od pet stupnjeva ( $1=$ uopće se ne slažem, $5=$ u potpunosti se slažem). Teorijski raspon kompozitne mjere iznosio je $4-20$ (viši rezultat označavao je višu razinu klerikalizma), a njezina pouzdanost bila je vrlo visoka (Cronba$\operatorname{chov} \alpha=0,91)$.

Seksualni konzervativizam mjeren je s pomoću triju čestica (npr. "Kad je riječ o seksualnosti, vjera je moj vodič"). Skala je razvijena i testirana u okviru nacionalne studije seksualnosti mladih (Puzek, Štulhofer i Božičević, 2012). Česticama je bila pridružena uobičajena skala slaganja od pet stupnjeva. Teorijski raspon kompozitne mjere iznosio je 3 - 15 (viši rezultat označavao je višu razinu mjerenog svojstva), a njezina je pouzdanost bila zadovoljavajuća (Cronbachov $\alpha=0,80$ ).

Kao mjera rodnog tradicionalizma primijenjena je validirana skala (Sekulić, 2011; Sekulić i Šporer, 2006) s četirima česticama (npr. "Ako je samo jedan partner zaposlen, prirodno je da to bude muškarac"; "Većina poslova u domaćinstvu po svojoj prirodi više odgovara ženama"). Pri procjeni čestica korištena je standardna skala slaganja od pet stupnjeva. Teorijski raspon kompozitne mjere iznosio je 4 20 (viši rezultat označavao je višu razinu mjerenog svojstva), a njezina je pouzdanost bila vrlo zadovoljavajuća (Cronbachov $\alpha=0,87$ ). 


\subsection{Analitička strategija}

Za konstrukciju i provjeru dimenzionalnosti VIDA-e korištena je konfirmacijska faktorska analiza s robusnom DWLS (engl. diagonally weighted least squares) procjenom parametara koja se koristi u slučaju značajnih odstupanja manifesnih varijabli od normalne distribucije kakva su bila prisutna i u ovoj studiji (RhemtuIla, Brosseau-Liard i Savalei, 2012). ${ }^{3} \mathrm{U}$ prvom su koraku analizirane mjere pristajanja svake podskale društvenog angažmana. ${ }^{4}$ Potom je konfirmacijska analiza provedena na cijelom instrumentu, pri čemu smo usporedili pristajanje četvero $\mathrm{i}$ trodimenzionalnog modela. $U$ trećem koraku, primjenom višegrupne analize, provjerena je invarijatnost VIDA-e s obzirom na spol sudionika. Shodno smjernicama (Putnick i Bornstein, 2016), invarijatnost je potvrđena ako su razlike u pristajanju konfiguralno, metrijski i skalarno invarijatnih (ugniježđenih) modela manje od 0,01 za indeks komparativnog pristajanja (CFI) te manje od 0,015 za korijen iz prosječne kvadrirane pogreške aproksimacije (RMSEA). Veličina ostvarenog uzorka bila je dovoljna za provođenje navedenih analiza bez obzira na to uzme li se kao kriterij broj sudionika po parametru koji treba izračunati ili po količini manifestnih varijabli uključenih u modele (npr., Hair i dr., 2010: 635-637; Kline, 2005: 111).

3 Konfirmacijska faktorska analiza statistički je primjerena metoda provjere konstrukcijske valjanosti kompozitnih mjernih instrumenata (npr., Kline, 2005; Hair i dr., 2010). Za razliku od eksploracijske faktorske analize i analize glavnih komponenti, koje se za tu svrhu još uvijek često koriste, konfirmacijska faktorska analiza izravno testira hipotetski model koji je apriorno konstruiran temeljem operacionalizacije određene teorije ili nalaza prethodnih istraživanja. Provedbom te analize određuje se stupanj pristajanja prikupljenih podataka strukturi latentnog prostora pretpostavljenog modelom, odnosno procjenjuje se koliko je teorijska (pretpostavljena, na temelju modela procijenjena) matrica kovarijanci podudarna s empirijskom (temeljem podataka izračunatom) matricom kovarijanci.

$4 \quad$ Uz neizostavni hi-kvadrat test korišteni su još i indeks komparativnog pristajanja (CFI), TuckerLewisov indeks (TLI) te korijen prosječne kvadrirane pogreške aproksimacije (RMSEA). Upravo se s pomoću mjera pristajanja (goodness-of-fit indikatora) u konfirmacijskoj faktorskoj analizi procjenjuje ranije spomenuto korespondiranje teorijske i empirijske matrice kovarijanci. Temeljni je indikator pristajanja hi-kvadrat test, čiji se rezultati navode i ovdje, no taj je test često neupotrebljiv pri analizama koje se provode na velikim uzorcima $(\mathrm{N}>250)$ budući da je u tim situacijama statistički značajna već i razlika (količina neprotumačene varijance) koja proizlazi iz malih, trivijalnih, odstupanja teorijske od empirijske matrice kovarijance (Hair i dr., 2010: 641, 647). Zbog toga se navode i dodatne mjere pristajanja poput CFI, TLI i RMSEA-e. Rezultatima koji indiciraju dobro pristajanje modela za CFI i TLI smatraju se vrijednosti bliske iznosu 1, a prihvatljivim 0,9 (taj iznos kod mjere CFI znači da se modelom može reproducirati $90 \%$ količine zajedničkog variranja podataka), dok su za RMSEA to vrijednosti bliske iznosu nuli. Prihvatljivo pristajanje za tu mjeru iznosi < 0,08 (Hair i dr., 2010: 642; Kline, 2005: 139). 
Konstruktna i kriterijska valjanost VIDA-e provjerena je analizom povezanosti između aditivnih vrijednosti središnje skale (i njezinih pojedinih podskala) te konceptualno srodnih konstrukata (klerikalizam, seksualni konzervativizam i rodni tradicionalizam), odnosno mjera religioznosti (participacijska i intrinzična religioznost). Multinomijalnom regresijskom analizom provjerena je diskriminacijska valjanost VIDA s obzirom na obiteljski odgoj u vjerskom duhu.

Sve su analize provedene s pomoću statističkih paketa jamovi v1.2 i JASP v0.11.1.

\section{REZULTATI}

Konfirmacijska faktorska analiza podskale humanitarnog rada uputila je na njezino prihvatljivo pristajanje podacima: $X^{2}(2)=6,49, p=0,039, \mathrm{CFI}=0,985, \mathrm{TLI}=0,954$, RMSEA = 0,064 (Cl90\%: 0,012-0,122). Ostale tri podskale bile su obilježene vrlo dobrim pristajanjem: podskala evangelizacijskog angažmana: $X^{2}(2)=2,56, p=$ 0,277, CFI = 0,999, TLI = 0,996, RMSEA = 0,023 (CI90\%: 0,000-0,091); podskala građanskog angažmana: $X^{2}(2)=0,15, p=0,925, \mathrm{CFI}=1,000, \mathrm{TLI}=1,000, \mathrm{RMSEA}$ = 0,000 (Cl90\%: 0,000-0,028); te podskala političkog angažmana: $X^{2}(2)=2,32, p$ $=0,314, \mathrm{CFI}=0,999, \mathrm{TLI}=0,997, \mathrm{RMSEA}=0,017$ (CI90\%: 0,000-0,088). Cronbachov a koeficijent podskala iznosio je, redom navođenja, 0,81, 0,92, 0,94 i 0,92, uz teorijski raspon rezultata tih kompozitnih mjera 0 - 12 (viši rezultat označava višu razinu angažmana određene vrste).

U sljedećem je koraku, kao četverodimenzionalna mjera, konfirmacijskom faktorskom analizom provjerena cijela VIDA. Mjere pristajanja ukazale su na odlično pristajanje modela podacima: $X^{2}(98)=118,45, p=0,078, C F I=0,996$, TLI $=0,995$, RMSEA = 0,019 (CI90\%: 0,000-0,031). Pouzdanost skale iznosila je visokih $a$ $=0,90$ (taj rezultat, doduše, treba uzeli s rezervom s obzirom na odstupanja od optimalnih pretpostavki za računanje Cronbachovog a koeficijent, osobito u vidu distribucije većine čestica te višedimenzionalnosti predmeta mjerenja). Povezanosti između pojedinih dimenzija (podskala) varirale su u rasponu od 0,42 do 0,93. S obzirom na iznimno visoku korelaciju između dimenzija građanskog i političkog angažmana $(r=0,93)$ te visoku internu konzistentnost skale koja obuhvaća čestica tih dviju dimenzija (Cronbachov $\alpha=0,91$ ), testirali smo i trodimenzionalni model u kojem su te dimenzije združene u jednu. Odlično pristajanje dobiveno je i za taj model: $X^{2}(101)=125,83, p=0,048, C F I=0,995, T L I=0,994$, RMSEA = 0,021 (CI90\%: 0,002-0,032). Usporedba četverofaktorskog i trofaktorskog modela pokazala je kako prvi, kompleksniji, model ne pridonosi statistički značajno tumačenju prikupljenih podataka u odnosu na drugi, jednostavniji, model $\left(\Delta X^{2}(3)=7,38\right.$; 
$p=0,061)$. Shodno tome, VIDA je operacionalizirana kao trodimenzionalna mjera (Slika 1).

Slika 1. Rezultati konfirmacijske faktorske analize trodimenzionalnog modela VIDA-e

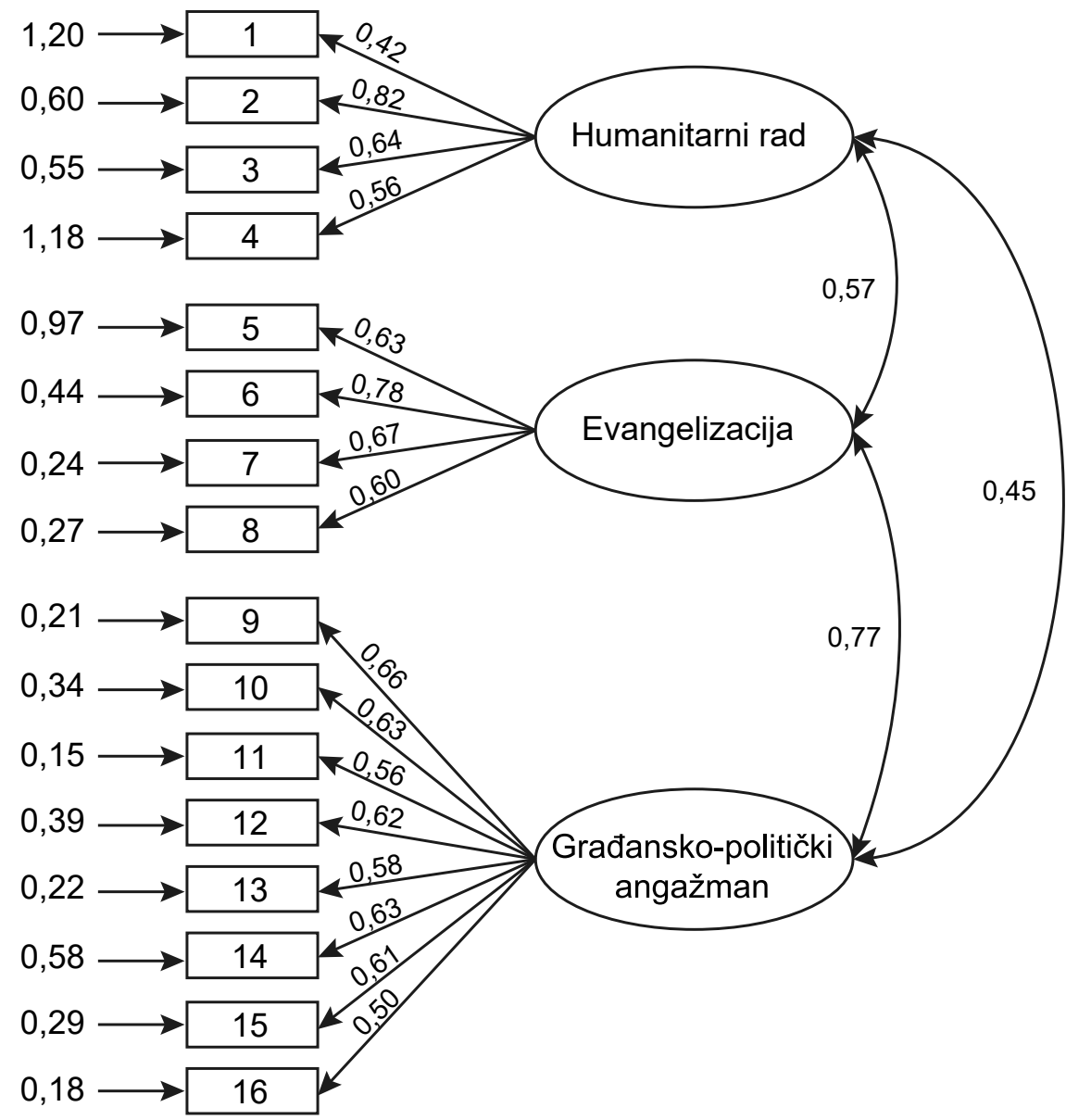

Napomena: zdesna nalijevo, vrijednosti koje se prikazuju u sklopu tog modela odnose se na standardizirane kovarijance, odnosno koeficijente korelacije (bivarijatna povezanost triju latentnih dimenzija VIDA-e), zatim faktorska otežanja (saturacije čestica pripadajućim latentnim dimenzijama) te varijancu pogreške (varijabilitet čestica neprotumačen njihovim odnosom s pripadajućom latentnom dimenzijom). 
Potom smo testirali mjeri li VIDA jednako dobro angažman ženskih i muških sudionika. Imajući u vidu neznačajne razlike u CFI i RMSEA između konfiguralno i metrijski invarijatnog modela $(\triangle C F I=0,003, \triangle R M S E A=0,015)$ te između metrijski i skalarno invarijatnog modela $(\triangle \mathrm{CFI}=0,002, \triangle \mathrm{RMSEA}=0,005)$, potvrđena je potrebna (skalarna) razina spolne invarijatnosti nove mjere.

U skladu s očekivanjima, VIDA je kao cjelovita mjera bila pozitivno povezana s klerikalizmom, seksualnim konzervativizmom i rodnim tradicionalizmom (Tablica 3), čime je indicirana njezina konstruktna valjanost. Pozitivne su korelacije tih triju konstrukata utvrđene i s podskalama VIDA-e, uz iznimku povezanosti humanitarnog angažmana s rodnim konzervativizmom.

Tablica 3. Pearsonovi koeficijenti korelacije i deskriptivni podaci o ključnim indikatorima

\begin{tabular}{|c|c|c|c|c|c|c|c|c|c|c|}
\hline & & & & Koeficij & jenti ko & relacije & & & & \\
\hline & (1) & (2) & (3) & (4) & (5) & (6) & (7) & (8) & (9) & \\
\hline (1) VIDA (0-3) & 1 & & & & & & & & & $0,66(0,57)$ \\
\hline $\begin{array}{l}\text { (2) Podskala: } \\
\text { humanitarni rad (0-3) }\end{array}$ & - & 1 & & & & & & & & $1,21(0,78)$ \\
\hline $\begin{array}{l}\text { (3) Podskala: } \\
\text { evangelizacija (0-3) }\end{array}$ & - & $0,43^{* *}$ & 1 & & & & & & & $0,63(0,75)$ \\
\hline $\begin{array}{l}\text { (4) Podskala: } \\
\text { građansko-politički } \\
\text { angažman }(0-3)\end{array}$ & - & $0,34^{* *}$ & $0,66^{* *}$ & 1 & & & & & & $0,40(0,63)$ \\
\hline (5) Klerikalizam (1-5) & $0,47^{* *}$ & $0,13^{*}$ & $0,50^{* *}$ & $0,47^{* *}$ & 1 & & & & & $1,95(1,08)$ \\
\hline $\begin{array}{l}\text { (6) Seksualni } \\
\text { konzervativizam (1-5) }\end{array}$ & $0,37^{* *}$ & $0,10^{*}$ & $0,43^{* *}$ & $0,35^{* *}$ & $0,72^{* *}$ & 1 & & & & $2,28(1,19)$ \\
\hline $\begin{array}{l}\text { (7) Rodni } \\
\text { tradicionalizam (1-5) }\end{array}$ & $0,24^{* *}$ & $-0,03$ & $0,26^{* *}$ & $0,31^{* *}$ & $0,48^{* *}$ & $0,52^{* *}$ & 1 & & & $1,89(0,95)$ \\
\hline $\begin{array}{l}\text { (8) Učestalost odlazaka } \\
\text { na vjerske obrede (1-7) }\end{array}$ & $0,45^{* *}$ & $0,19^{* *}$ & $0,53^{* *}$ & $0,38^{* *}$ & $0,58^{* *}$ & $0,59^{* *}$ & $0,35^{* *}$ & 1 & & $3,78(1,64)$ \\
\hline $\begin{array}{l}\text { (9) Intrinzična } \\
\text { religioznost (1-5) }\end{array}$ & $0,44^{* *}$ & $0,19^{* *}$ & $0,51^{* *}$ & $0,38^{* *}$ & $0,67^{* *}$ & $0,63^{* *}$ & $0,34^{* *}$ & $0,70^{* *}$ & 1 & $2,70(1,25)$ \\
\hline
\end{tabular}

Napomena: rezultati kompozitnih mjera svedeni su na originalnu skalu mjerenja (navedenu $u$ zagradi iza svake mjere) dijeljenjem skupnog rezultata s brojem čestica.

${ }^{*} p<0,05 ;{ }^{* *} p<0,01$ 
U pogledu kriterijske valjanosti, rezultati korelacijske analize (Tablica 3) pokazali su da je veći rezultat na VIDA-i bio povezan s učestalijim pohađanjem vjerskih obreda te većim stupnjem intrinzične religioznosti. Potvrđena je i diskriminacijska valjanost nove mjere. Prema rezultatima multinomijalne logističke regresijske analize, veći rezultat na VIDA-i bio je povezan s većim izgledima da su se u sudionikovoj obitelji striktno poštovala i provodila vjerska načela - usporedimo li ih sa sudionicima koji nisu bili odgajani u vjerskom duhu $(O R=1,08, p<0,001)$.

\section{RASPRAVA}

Polazeći od potrebe za složenim instrumentom koji bi mjerio angažman mladih ljudi u vjerom motiviranim i/ili religijskim vrijednostima inspiriranim organizacijama te društvenim aktivnostima, u ovome smo radu opisali proces izrade i provjere valjanosti nove mjere (VIDA-e). Temeljem kvalitativnih podataka, formirali smo 16 čestica čija je struktura povezanosti potom testirana u nacionalnom internetskom uzorku mladih u dobi između 18 i 25 godina. Prema očekivanju temeljenom na procjenama zastupljenosti građana postojane i intenzivne osobne i institucionalne religioznosti u hrvatskom društvu (Nikodem i Zrinščak, 2019a), među kojima postoji najveći potencijal za vjerom inspirirano društveno djelovanje, većina je oblika angažmana predviđanih VIDA-om razmjerno rijetka, odnosno svojstvena manjoj skupini religioznih mladih ljudi (usp. Tablicu 2). Provedene validacijske analize ukazale su na višedimenzionalnost mjere, pri čemu smo identificirali tri poddimenzije: humanitarni, evangelizacijski te građansko-politički angažman. Provjera nove mjere potvrdila je njezinu kriterijsku, konstruktnu i diskriminacijsku valjanost. Rezultati na VIDA-i bili su statistički značajno povezani s učestalošću sudjelovanja u vjerskim obredima te s intrinzičnom religioznošću, a jednako tako i sa srodnim (teorijski povezanim) konstruktima klerikalizma, seksualnog konzervativizma te rodnog tradicionalizma. Također, VIDA je statistički značajno razlikovala sudionike koji su odgojeni u duhu vjere i religije od onih kod kojih to nije bio slučaj. Potrebno je još napomenuti kako je za VIDA-u potvrđena spolna invarijatnost, odnosno podjednako dobro mjerenje vjerom inspiriranog društvenog angažmana kod ženskih i kod muških sudionika kao i kod svih sudionika, neovisno o spolu. Iz toga proizlazi da se VIDA-u može koristiti u budućim istraživanjima koja bi ciljevima bila usmjerena na utvrđivanje spolnih razlika u vjerski inspiriranom društvenom angažmanu te $u$ istraživanjima koja se provode samo na djevojkama ili samo na mladićima.

Identifikacija triju poddimenzija vjerom inspiriranoga društvenog angažmana ima eksplorativnu vrijednost u razumijevanju društvene uloge religije u hrvatskom društvu. Zbog specifičnih prilika u socijalističkom razdoblju, laički crkveni pokreti bili su, uz malobrojne iznimke, "uvezeni” te pretežno evangelizacijski usmjereni, u 
mjeri u kojoj su to mogli biti u nedemokratskom sustavu. Kako demokratizacija donosi nove mogućnosti djelovanja u društvu, društveni angažman vjernika postaje vrlo heterogen te ulazi u različita područja društvenog života. S obzirom na to da se u literaturi dosad o angažmanu vjernika-laika raspravljalo pretežno načelno, uglavnom iz perspektive potreba i mogućnosti toga angažmana, ovaj rad nudi poticaj daljnjoj analizi evidentnih razlika u vjerom inspiriranom društvenom angažmanu. Osobito se zanimljivim pokazalo da su građanski i politički angažman visoko korelirani te zapravo čine jednu poddimenziju. Sukladno već uočenoj povezanosti intenzivne religioznosti s desnom političkom orijentacijom i nacionalnim identitetom, a što je analizirano u okviru koncepta etno-religioznosti (Nikodem i Zrinščak, 2019b), ova analiza dalje potvrđuje da etno-religioznost (p)ostaje, ako ne dominantan, a onda svakako prepoznatljiv tip religioznosti u Hrvatskoj.

$\mathrm{Na}$ tom se tragu otvara niz pitanja za daljnja istraživanja u kojima VIDA može poslužiti kao važna mjera. Prvo, zašto se civilni ili građanski vjerom inspirirani angažman ne uspijeva razviti neovisno o političkim pitanjima i podjelama? Drugo, je li stoga moguće predvidjeti daljnje ideološke rascijepe u hrvatskom društvu s obzirom na, s jedne strane, uočenu polarizaciju vjerničke populacije a, s druge strane, činjenice da građani u Hrvatskoj, kao i u nizu postsocijalističkih zemalja, očekuju društveni, ali odbacuju politički angažman Crkve (Ančić i Zrinščak, 2012)? Treće, u kojoj mjeri vjernički društveno-politički angažman inkorporirati u tradicionalnu analizu Crkveno-državnih odnosa jer je očito da se društvena scena pluralizirala te da Crkveno-državne odnose više nije moguće razumjeti bez inkorporacije niza novih relevantnih javnih aktera? Četvrto, s obzirom na važnost odgoja u duhu vjere za vjerom inspirirani društveni angažman, a osobito s obzirom na rasprave o vjeronauku u školama, koje su to dimenzije odgoja u duhu vjere koje pokazuju diskriminatornu vrijednost za društveni angažman? Ovdje valja naglasiti da se primjenom VIDA-e ne mjeri niti indicira specifična motivacija mladih za vjerom inspirirano društveno djelovanje. Osim u intrinzičnoj religioznosti, ta bi motivacija mogla biti utemeljena i u nekima od individualnih ili skupnih iskaza ekstrinzične religioznosti poput učinaka šire društvene okoline (vršnjački utjecaji, članstvo u crkvenim udruženjima i župama i slično) ili socijalizacije u obitelji u kojima su roditelji na sličan način društveno angažirani (Vermeer i Scheepers, 2019; Gibson, 2008; Yeung, 2017; Van Goethem i dr., 2014). Mjerenje tih dodatnih obilježja u istraživanjima koja će koristiti VIDA-u kao iskaz religioznosti mladih moglo bi pospješiti doseg analiza i nijansiranost njihovih nalaza. 


\subsection{Ograničenja studije}

Potrebno se osvrnuti i na temeljne nedostatke ovog istraživanja. Prvo, regrutacija sudionika u kvalitativnu dionicu istraživanja bila je obilježena slabim odazivom. To je ograničenje barem dijelom ublaženo ranom indikacijom tematskog zasićenja, odnosno ponavljanja većine iskustava i praksi već nakon šestog od ukupno trinaest intervjua. Drugo, u uzorku iz kvantitativnog dijela istraživanja nadzastupljeni su sudionici u dobi od 18 i 19 godina (34\%) u odnosu na one u dobi od 24 i 25 godina $(14,7 \%)$. Premda to utječe na dobnu reprezentativnost, analitička narav studije (konstrukcija i validacija nove mjere) ne zahtijeva reprezentativni, nego dovoljno velik i heterogen uzorak. Treće, indikatori pojedinih tipova angažmana ne reflektiraju jednaku razinu i intenzitet angažiranosti. Primjerice, sudionici koji glasaju na izborima za neku političku stranku nisu jednako angažirani kao oni koji su sudjelovali u predizbornoj kampanji te stranke. No, zbog nedostatka empirijskih podataka iz prethodnih istraživanja ovog predmeta mjerenja zasad nema mogućnosti naknadnog uravnoteživanje pojedinih indikatora. To se ograničenje reflektira i na upotrebljivost VIDA-e kao kompozitne mjere, odnosno ukazuje na potrebu za njezinim latentnim modeliranjem. Taj je oblik uporabe VIDA-e primjereniji od korištenja u obliku kompozitne mjere iz zbog toga što je instrument višedimenzionalan, premda razmjerno visoka povezanost među svim dimenzijama i vrlo visoka interna konzistentnost računata za sve čestice koje tvore VIDA-u upućuju na zaključak da je riječ o jedinstvenom predmetu mjerenja koji obilježava nekoliko distinktnih aspekata. Četvrto, valja podsjetiti na nešto lošija metrijska obilježja podskale humanitarnog angažmana u odnosu na rezultate ostvarene za ostale tri, odnosno dvije, podskale VIDA-e (nešto niže razine pristajanja modela podacima, povezanosti s validacijskim mjerama i interne konzistentnosti). Premda ta obilježja i dalje upućuju barem na prihvatljivu valjanost i pouzdanost podskale humanitarnog angažmana, ostaje upitno zbog čega je tome tako. Je li uputa iz potke instrumenta o mjerenju učestalosti angažmana koji je inspiriran vjerom promaknuo dijelu nereligioznih sudionika, pa su bilježili i svoj humanitarni rad koji je imao drugu motivaciju? Suprotno tomu, moguće je i da je dio religioznih i angažiranih sudionika humanitarni rad smatrao univerzalnom, altruističkom, vrijednošću, odnosno iskazom ljudskosti koja nije (primarno) motivirana njihovom vjerom, pa iskustvo te vrste svojega društvenog angažmana nisu ni bilježili. Temeljem mjerenja i podataka ostvarenih u ovom istraživanju to pitanje nije moguće empirijski rasvijetliti, nego ostaje preporuka da se to učini u budućim provjerama ili primjenama VIDA-e. Napokon, treba istaknuti da VIDA svojim sadržajem nije usmjerena na pripadnike određene konfesije. Ipak, budući da je konstruirana i evaluirana dominantno među kršćanima, odnosno katolicima, bez daljnjih se provjera ne može smatrati validiranom mjerom vjerom inspiriranoga društvenog angažmana među mladima drugih vjeroispovijesti. 


\section{ZAKLJUČAK}

S obzirom na potrebu za empirijskom analizom suvremenih fenomena vezanih uz religioznost, od mogućeg trenda polarizacije društva na izraženo vjerničku populaciju i onu distancirane religioznosti do utjecaja konzervativnih, vjerom inspiriranih, društvenih pokreta, u ovome je radu prikazan postupak konstrukcije i validacije instrumenta namijenjenog mjerenju vjerom inspiriranoga društvenog angažmana (VIDA) među mladima. Konfirmacijska faktorska analiza ukazala je na to da se VIDA sastoji od triju međusobno povezanih dimenzija humanitarnoga, evangelizacijskog te građansko-političkog angažmana. Dodatna su testiranja potvrdila visoku internu konzistentnost te kriterijsku, konstrukcijsku i diskriminacijsku valjanost nove mjere.

Prema prikazanim nalazima, VIDA je valjan, pouzdan i razmjerno kratak instrument čija bi primjena mogla znatno unaprijediti istraživanja religioznosti mladih $\mathrm{i}$ njezine povezanosti s nizom ponašajnih i stavovskih ishoda - $u$ rasponu od javnog zdravlja do političkih orijentacija. $U$ tom smislu, vrijednost nove mjere vidimo primarno u njezinom doprinosu preciznijim analizama uloge religioznosti u hrvatskom društvu osvjetljavanjem dimenzije religioznosti koja nije bila zahvaćena dosadašnjim empirijskim istraživanjima.

\section{FINANCIJSKA POTPORA}

Rad je nastao u sklopu projekta IP-2019-04-3609 Hrvatske zaklade za znanost. Istraživanje je sufinancirano sredstvima Sveučilišta u Zagrebu. 


\section{LITERATURA}

Ančić B i Zrinščak S (2012). Religion in Central and Eastern European Societies: Its Social Role and People's Expectations, Religion and Society in Central and Eastern Europe, 5 (1): 21-38.

Baloban J, Šimunović J i Ježovita J (2019). Kretanje crkvenosti u hrvatskom društvu od 1999. do 2017. godine. Analiza i kritički osvrt, Bogoslovska smotra, 89 (2): 412-441.

Baloban S (2011). Uvodnik. Primjena supsidijarnosti u hrvatskom društvu, Bogoslovska smotra, 81 (4): 721-728.

Baloban S (2012). Vjernici laici: neiskorišten društveni i crkveni potencijal u Hrvatskoj. Bogoslovska smotra, 82 (4): 1015-1035.

Bezinović P, Marinović-BobinacAi Marinović Jerolimov D (2005). Kratka ljestvica religioznosti: validacija na uzorku adolescenata. Društvena istraživanja, 14 (1-2): 135-153.

Bouillet D (2014). Rizična ponašanja studenata. U: Ilišin V (ur.). Sociološki portreti hrvatskih studenata. Zagreb: Institut za društvena istraživanja u Zagrebu, 399-340.

Campbell DE (2004). Acts of Faith: Churches and Political Engagement, Political Behavior 26: 155-180. https://doi.org/10.1023/B:POBE.0000035961.78836.5f

Cnaan RA, Pessi AB, Zrinščak S, Handy F, Brudney JL, Grönlund H, Haski-Leventhal D, Holems K, Hustinx L, Chulhee K, Kassam M, Meijs L, Ranade B, Smith KA i Yamauchi N (2012). Student Values, Religiosity, and Pro-Social Behaviour: A Cross-National Perspective, Diaconia: Journal for the Study of Christian Social Practice, 3 (1): 2-25. https://doi.org/10.13109/diac.2012.3.1.2

Čepo D (2017). Breeding Grounds for Croatia's Conservative Social Movements. U: Mujanović, J (ur.). The Democratic Potential of Emerging Social Movements in Southeastern Europe. Sarajevo: Friedrich-Ebert-Stiftung, 17-22.

Črpić G (2002). Volonterstvo kao novi oblik crkvenog služenja, Bogoslovska smotra, 72 (23): 423-433.

Črpić G i Mravunac D (2011). Pregled postotaka istraživanja "Supsidijarnost u hrvatskom društvu", Bogoslovska smotra, 81 (4): 731-752.

Črpić G i Zrinščak S (2010). Dinamičnost u stabilnosti: religioznost u Hrvatskoj 1999. i 2008. godine, Društvena istraživanja, 19 (1-2): 3-27.

Čulig B (2004). Analiza političkih stavova stanovništva Hrvatske, Socijalna ekologija, 13 (3-4): 287-304.

Čulig B, Klasnić K i Jakšić J (2011). Empirijska verifikacija tipologije ateizma, Revija za sociologiju, 41 (2): 185-212. https://doi.org/10.5613/rzs.41.2.3

Čulig,B, Kufrin,K i Landripet I (2007). EU + ? - Odnos građana Hrvatske prema pridruživanju Republike Hrvatske Europskoj uniji. Zagreb: FF press i B.a.B.e.

Darvyri P, Galanakis M, Avgoustidis AG, Pateraki N, Vasdekis S i Darvyri C (2014). The Revised Intrinsic/Extrinsic Religious Orientation Scale in a Sample of Attica's Inhabitants, Psychology, 5 (13): 1557-1567. https://doi.org/10.4236/psych.2014.513166

De Hart J, Dekker P i Halman L (ur.) (2013). Religion and Civil Society in Europe. Dordrecht: Springer. https://doi.org/10.1007/978-94-007-6815-4

Driskell RL, Lyon L i Embry E (2008). Civic Engagement and Religious Activities: Examining the Influence of Religious Tradition and Participation, Sociological Spectrum, 28 (5): 578-601. https://doi.org/10.1080/02732170802206229 
Droege JR i Ferrari JR (2012). Toward a New Measure for Faith and Civic Engagement: Exploring the Structure of the FACE Scale, Christian Higher Education, 11 (3): 146-157. https://doi.org/10.1080/15363751003780852

Garelli F (2013). Religion and Civil Society in Italy and in Other Latin Countries. U: De Hart, J, Dekker, P i Halman, L. (ur.). Religion and Civil Society in Europe. Dordrecht: Springer, 125-146. https://doi.org/10.1007/978-94-007-6815-4_7

Gibson T (2008). Religion and Civic Engagement among America's Youth, The Social Science Journal, 45 (3): 504-514, https://doi.org/10.1016/j.soscij.2008.07.007

Gvozdanović A, llišin V, Adamović M, Potočnik D, Baketa N i Kovačić M (2019). Istraživanje mladih u Hrvatskoj 2018./2019. Zagreb: Friedrich-Ebert-Stiftung.

Hair JF, Black WC, Babin BJ i Anderson RE (2010). Multivariate Data Analysis (Seventh Edition). New Jersey: Prentice Hill.

Hodžić Ai ŠtulhoferA(2017). Embryo, Teddy Bear-centaur and the Constitution: Mobilizations against "Gender Ideology" and Sexual Permissiveness in Croatia. U: Paternotte, D i Kuhar, R (ur.). Anti-Gender Campaigns in Europe: Mobilizing against Equality. London: Rowman \& Littlefield, 59-77.

Ilišin V (2017). Mladi i politika: trendovi (dis)kontinuiteta. U: llišin, V i Spajić Vrkaš, V (ur.). Generacija osujećenih: mladi u Hrvatskoj na početku 21. stoljeća. Zagreb: Institut za društvena istraživanja u Zagrebu, 185-259.

Jugović I i Ančić B (2013). Effects of Religiosity and Spirituality on Gender Roles and Homonegativity in Croatia and Slovenia. U: Furlan Štante, N i Harcet, M (ur.). Spirituality of Balkan Women: Breaking Boundaries. The Voices of Women of Ex-Yugoslavia. Ljubljana: University of Primorska, Science and Research Centre, Annales University Press, 93-118.

Kline RB (2005). Principles and Practice of Structural Equation Modeling (Second Edition). New York: Guilford Press.

Marinović Jerolimov D (2002). Religioznost, nereligioznost i neke vrijednosti mladih. U: Ilišin, V i Radin, F (ur.). Mladi uoči trećeg milenija. Zagreb: Institut za društvena istraživanja, 79-124.

Marinović Jerolimov D i Jokić B (2010). Religion and Youth in Croatia, Annual Review of the Sociology of Religion, 1: 307-327. https://doi.org/10.1163/ej.9789004187900.i-488.89

Marinović Jerolimov D i Ančić B (2014). Religioznost i stavovi prema seksualnosti i braku odrasle populacije u Hrvatskoj, Društvena istraživanja, 23 (1): 111-132. https://doi. org/10.5559/di23.1.06

Mencken FC i Fitz B (2013). Image of God and Community Volunteering among Religious Adherents in the United States. Religious Research Association, 55: 491-508. https:// doi.org/10.1007/s13644-013-0115-4

Mihaljević V (2005). Društveni kontekst i teorijsko-hipotetski okvir istraživanja "Novi laički crkveni pokreti u Hrvatskoj", Društvena istraživanja, 14 (1-2): 3-25.

Nikodem K i Zrinščak S (2019a). Između distancirane crkvenosti i intenzivne osobne religioznosti: religijske promjene u hrvatskom društvu od 1999. do 2018. godine, Društvena istraživanja, 28 (3): 371-390. https://doi.org/10.5559/di.28.3.01

Nikodem K i Zrinščak S (2019b). Etno-religioznost: Religioznost, nacionalni identitet i političke orijentacije u hrvatskom društvu. U: Šimunović J i Migles S (ur.). Uzvjerovah, zato besjedim (2 Kor 4,13). Zbornik u čast Prof. dr. sc. Josipa Balobana povodom 70. godine života. Zagreb: KBF i Kršćanska sadašnjost, 431-449. 
Paternotte D i Kuhar R (ur.) (2017). Anti-Gender Campaigns in Europe: Mobilizing against Equality. London: Rowman \& Littlefield

Peračković K i Mihaljević V (2005). Analiza strukture članstva i temeljna obilježja pokreta "Franjevačka mladež" - jedan primjer postmodernoga crkvenog pokreta, Društvena istraživanja, 14: (1-2), 47-69.

Petričušić A, Čehulić M i Čepo D (2017). Gaining Political Power by Utilizing Opportunity Structures: An Analysis of the Conservative Religious-Political Movement in Croatia, Politička misao, 54 (4): 61-84.

Polson EC (2018). An Examination of the Relationship Between Characteristics of Sect-Like Religiosity and Community Volunteering Among U.S. Churchgoers, Review of Religious Research, 60: 247-274. https://doi.org/10.1007/s13644-017-0315-4

Putnick DL i Bornstein MH (2016). Measurement Invariance Conventions and Reporting: The State of the Art and Future Directions for Psychological Research, Developmental Review, 41: 71-90. https://doi.org/10.1016/j.dr.2016.06.004

Puzek I, Štulhofer A i Božičević I (2012). Is Religiosity a Barrier to Sexual and Reproductive Health? Results from a Population-based study of Young Croatian Adults, Archives of Sexual Behavior, 41 (6): 1497-1505. https://doi.org/10.1007/s10508-012-9924-8

Ray D (2017). Religion and Civic Engagement. U: Dolgon, C, Mitchell, Ti Eatman, T (ur.). The Cambridge Handbook of Service Learning and Community Engagement. Cambridge: Cambridge University Press, 42-50. https://doi.org/10.1017/9781316650011.005

Ratzinger J (2003). Doktrinalna nota o nekim pitanjima vezanim uz sudjelovanje katolika u političkom životu. Zagreb: Izvještajna katolička agencija.

Rhemtulla M, Brosseau-Liard PÉ i Savalei V (2012). When Can Categorical Variables Be Treated as Continuous? A Comparison of Robust Continuous and Categorical SEM Estimation Methods under Suboptimal Conditions, Psychological Methods, 17 (3): 354373. https://doi.org/10.1037/a0029315

Ruiter S i de Graaf ND (2006). National Context, Religiosity, and Volunteering: Results from 53 Countries, American Sociological Review, 71: 191-210. https://doi. org/10.1177/000312240607100202

Sekulić D (2011). Vrijednosno-ideološke orijentacije kao predznak i posljedica društvenih promjena, Politička misao, 84 (3): 35-64.

Sekulić D i Šporer Ž (2006). Religioznost kao prediktor vrijednosnih orijentacija, Revija za sociologiju, 37 (1-2): 1-19.

Son J i Wilson J (2012). Using Normative Theory to Explain the Effect of Religion and Education on Volunteering, Sociological Perspectives, 55 (3): 473-499. https://doi. org/10.1525/sop.2012.55.3.473

Storm I (2015). Civic Engagement in Britain: The Role of Religion and Inclusive Values, European Sociological Review, 31 (1): 14-29. https://doi.org/10.1093/esr/jcu077

Šram Z (2008). Etnocentrizam, autoritarne tendencije i religioznost: relacije na uzorku zagrebačkih studenata, Migracijske i etničke teme, 24 (1-2): 49-66.

Štimac Radin H (2014). Studentska populacija o ravnopravnosti spolova i političkoj participaciji žena. U: llišin, V (ur.). Sociološki portreti hrvatskih studenata. Zagreb: Institut društvenih istraživanja u Zagrebu, 321-342.

Tadić S (2002). Tražitelji svetoga. Prilog fenomenologiji eklezijalnih pokreta. Zagreb: Institut društvenih znanosti Ivo Pilar. 
Trimble DE (1997). The Religious Orientation Scale: Review and Meta-Analysis of Social Desirability Effects, Educational \& Psychological Measurement, 57 (6): 970-986. https:// doi.org/10.1177/0013164497057006007

Van Goethem AAJ, van Hoof A, van Aken MAG, de Castro BO i Raaijmakers QAW (2014). Socialising Adolescent Volunteering: How Important are Parents and Friends? Age Dependent Effects of Parents and Friends on Adolescents' Volunteering Behaviours, Journal of Applied Developmental Psychology, 35 (2): 94-101. https://doi.org/10.1016/j. appdev.2013.12.003

Veeh CA, Plassmeyer M, Nicotera N i Brewer SA (2019). A Combined Measure of Civic Engagement for Use Among Emerging Adults, Journal of the Society for Social Work and Research, 10 (1): 13-34. https://doi.org/10.1086/701948

Vermeer P i Scheepers P (2012). Religious Socialization and Non-religious Volunteering: A Dutch panel study, Voluntas, 23: 940-958. https://doi.org/10.1007/s11266-011-9244-y

Vermeer P i Scheepers P (2019). Bonding or Bridging? Volunteering Among the Members of Six Thriving Evangelical Congregations in the Netherlands, Voluntas, 30: 962-975. https://doi.org/10.1007/s11266-019-00160-1

Vučković A i Črpić G (2007). Religioznost i praštanje, Društvena istraživanja, 16 (6): 12011218.

Vučković Juroš T, Dobrotić I i Flego S (2020). The Rise of the Anti-Gender Movement in Croatia and the 2013 Marriage Referendum, Europe-Asia Studies, 72 (9): 1523-1553. https://doi.org/10.1080/09668136.2020.1820956

Yeung JWK (2017). Religious Involvement and Participation in Volunteering: Types, Domains and Aggregate, Voluntas, 28: 110-138. https://doi.org/10.1007/s11266-016-9756-6

Zrinščak S (2001). Ima neka tajna veza: religioznost mladih kao indikator društvenih i religijskih promjena, Društvena istraživanja, 10 (1-2): 19-40.

Zrinščak S, Marinović Jerolimov D, Marinović A i Ančić B (2014). Church and State in Croatia: Legal Framework, Religious Instruction, and Social Expectations. U: Ramet, SP (ur.). Religion and Politics in Post-Socialist Central and Southeastern Europe. London: Palgrave Macmillan, 131-154. https://doi.org/10.1057/9781137330727_6 


\title{
Construction and Evaluation of the Faith-Based Social Engagement Scale (VIDA) among Emerging Croatian Adults
}

\author{
Ivan LANDRIPET (D) https://orcid.org/0000-0002-6276-9742
}

Faculty of Humanities and Social Sciences, University of Zagreb, Croatia ilandrip@ffzg.hr

Goran KOLETIĆ (iD https://orcid.org/0000-0003-0976-1685

Faculty of Humanities and Social Sciences, University of Zagreb, Croatia gkoletic@ffzg.hr

Luka JURKOVIĆ (iD https://orcid.org/0000-0003-0407-3832

Faculty of Humanities and Social Sciences, University of Zagreb, Croatia ljurkovi@ffzg.hr

Siniša ZRINŠČAK (D) https://orcid.org/0000-0003-3542-0585

Faculty of Law, University of Zagreb, Croatia

sinisa.zrinscak@pravo.hr

\section{Aleksandar ŠTULHOFER (iD) https://orcid.org/0000-0001-5138-3644 \\ Faculty of Humanities and Social Sciences, University of Zagreb, Croatia astulhof@ffzg.hr}

\section{ABSTRACT}

Globally, religious institutions and faith-based civic associations are encouraging believers, particularly young people, to actively advocate and defend religious values. While in Croatia religious social engagement has been promoted and practised for decades, this form of religiosity remained unexplored. To facilitate research on the prevalence, background, types, and outcomes of such collective activity, this paper presents the construction and evaluation of a faith-based social engagement scale. Based on qualitative methods, 16 items indicating four dimensions of faith-based engagement (humanitarian, evangelical, civic, and political) were confirmatory factor analysed in a probability sample of emerging adults, aged $18-25$ years $(N=552)$, selected from a commercial online panel. The scale's validity was confirmed by associations with other measures of religiosity and religiosity-related attitudes and values. In addition to the satisfactory criterion, construct, and discriminative validity, the scale was genderinvariant and had high internal consistency. The conclusion features a brief discussion of limitations and a range of potential applications of this new measure.

Key words: faith-based social engagement, religiosity, religious practices, conservative social movement, emerging adults 